\title{
Overqualification of graduates: assessing the role of family background
}

\author{
Daniel Erdsiek $^{1}$
}

Published online: 24 August 2016

(C) The Author(s) 2016. This article is available at SpringerLink with Open Access.

\begin{abstract}
Overqualification signals a mismatch between jobs' educational requirements and workers' qualifications implying potential productivity losses at the macro and the micro level. This study explores how the family background of German graduates affects the probability to hold a job that does not require tertiary education, i.e. to be overqualified. Potential pathways of the family background effects are discussed and proxy variables for the mediating factors ability and skills, study characteristics, social capital, financial capital, and aspiration are incorporated into the empirical analysis. Graduates from high status families are found to be less likely to be overqualified. The unconditional social overqualification gap amounts to 7.4 percentage points. Blinder-Oaxaca decompositions of the overqualification gap show that differences in ability and skills, study characteristics, and social capital are important mediators of the family background effects.
\end{abstract}

I thank Melanie Arntz, Marianne Saam, Patrick Schulte, Konrad Stahl, Steffen Viete, two anonymous referees and the participants of the IAB PhD Workshop on (Un-)Employment, the Junior Research Dialogue Seminar at the University of Mannheim, the KIT-ZEW Workshop on Economics of Science, and the ZEW Workshop on Skill Mismatch for their valuable comments. This article was written as part of the project "Adequate employment of graduates: An economic analysis of job match quality" supported within the programme "Economics of Science" by the German Ministry of Education and Research (BMBF, research grant 01PW11019). All remaining errors are my sole responsibility.

Daniel Erdsiek

erdsiek@zew.de

1 Centre for European Economic Research (ZEW) Mannheim, P.O. Box 103443, 68034 Mannheim, Germany
Keywords Overqualification - Overeducation - Family background - Intergenerational mobility $\cdot$ Blinder-Oaxaca decomposition

JEL-Classification I23 $\cdot$ I24 $\cdot$ J24 $\cdot$ J62

\section{Überqualifikation von Hochschulabsolventen: Welche Rolle spielt der familiäre Hintergrund?}

Zusammenfassung Ein Mismatch zwischen den Anforderungen einer beruflichen Beschäftigung und den Fähigkeiten eines Arbeitnehmers kann Produktivitätsverluste auf der individuellen sowie gesamtwirtschaftlichen Ebene verursachen, weil das verfügbare Humankapital nicht ausreichend genutzt wird. Überqualifikation beschreibt eine entsprechende Situation in der ein Mismatch vorliegt, weil die Beschäftigung nicht den formalen Bildungsabschluss erfordert, den der Arbeitnehmer erworben hat. Diese Studie untersucht, inwieweit der familiäre Hintergrund von Hochschulabsolventen die Wahrscheinlichkeit beeinflusst, überqualifiziert beschäftigt zu sein. Mögliche Wirkungsmechanismen für einen Effekt der sozialen Herkunft werden diskutiert und anhand von Proxy-Variablen für die folgenden potentiellen Einflussfaktoren empirisch untersucht: individuelle Fähigkeiten, Charakteristika des Studiums, soziales Kapital, finanzielles Kapital und Karriereorientierung. Wie die Ergebnisse zeigen, sind Hochschulabsolventen aus Akademikerhaushalten seltener überqualifiziert beschäftigt als Bildungsaufsteiger - also Absolventen, deren Eltern nicht über einen Hochschulabschluss verfügen. Die Differenz der Überqualifikationsraten dieser beiden Absolventengruppen beträgt 7,4 Prozentpunkte. Eine Blinder-Oaxaca Dekomposition dieser Differenz zeigt, dass individuelle Fähig- 
keiten, Studieneigenschaften und soziales Kapital wichtige Wirkungsmechanismen für den Einfluss des familiären Hintergrunds auf das Risiko einer Überqualifikation darstellen.

\section{Introduction}

A large number of theoretical and empirical studies show that human capital is an important determinant of economic growth. Human capital captures the aggregate amount of skills and knowledge inherent in an economy's workforce. It is one of the main pillars of the European strategy for economic growth to promote human capital formation (EU2020). One related target is that a share of $40 \%$ of the population aged 30-34 will hold a tertiary degree by the year 2020 (European Commission 2010). However, human capital per se does not facilitate growth. In order to increase output, the stock of skills and knowledge has to be deployed by workers in the execution of tasks. Reaping the benefits of human capital investments requires that workers hold adequate jobs that make efficient use of their skills. Otherwise, imbalances between employer needs and skills of the workforce can lead to an underutilisation of the available human capital hampering economic growth. According to assignment theory, high-skilled workers holding jobs with low skill requirements underutilise their human capital and do not reach their individual production capacity (Sattinger 1993). In the literature, such vertical mismatches are commonly identified in terms of overqualification arising if individuals' current qualification exceeds the educational requirement of their job.

Overqualification entails productivity-related implications for both economies and individuals. At the aggregate level, reallocating mismatched workers to appropriate jobs could increase productivity and GDP (Gautier and Teulings 2015; McGowan and Andrews 2015). Thus, overqualification implies a potential waste and misallocation of scarce public resources, in particular those public funds invested into education (Chevalier 2003). At the individual level, mainly productivity-related outcomes, such as job satisfaction or wages, have been analysed (Hartog 2000). These studies commonly find that overqualified workers are less satisfied with their job which could reduce workers' motivation and effort leading to lower productivity (Hersch 1991; Korpi and Tåhlin 2009). Concerning the effects on wages, overqualified workers are found to earn more than their well-matched co-workers because surplus schooling is rewarded (Duncan and Hoffman 1981). However, the return on surplus schooling is commonly found to be lower than the return on years of schooling required for a job (Hartog 2000). Therefore, overqualified workers are found to earn less than equally educated workers holding a matching job (Büchel and Mertens 2004; Daly et al. 2000). Further stud- ies also indicate that overqualification comes along with significant wage penalties for the subgroup of graduates (Chevalier 2003; Diem and Wolter 2014). As discussed by Tsai (2010) and others, negative wage effects might partly arise from a selection of less able individuals into overqualification because individuals holding the same qualification might differ in (innate) ability. In this case, overqualification would not represent an underutilisation of available skills. Recent studies controlling for the skill-heterogeneity between equally educated individuals produced mixed results concerning the causal interpretation of the wage penalty for overqualification. In some studies the negative wage effect of overqualification vanishes once skill-heterogeneity is accounted for (Bauer 2002; Tsai 2010), while other studies find robust wage penalties (Kleibrink 2015; Korpi and Tåhlin 2009). Since previous findings suggest that overqualification is detrimental at the macro and the micro level, understanding the causes for the occurrence of mismatches is highly relevant from a policy perspective.

This study explores which factors are relevant determinants of overqualification among university graduates. Concentrating on the subgroup of graduates is meaningful from a policy perspective since increasing the share of highskilled workers is an important strategy to promote economic growth. A further aim of policies that improve the access to higher education is to increase intergenerational social mobility. A higher social mobility might in turn enhance growth through a better allocation of human capital resources inherent in individuals from disadvantaged family backgrounds (OECD 2010). In order to promote growth through social mobility, these human capital resources have to be put into productive use in the labour market. It is a special focus of this study to assess the importance of family background as a potential determinant of overqualification. In this context, the outcome variable of overqualification can be interpreted in two ways that are closely related. First, from a growth perspective, overqualification can be interpreted as an indication for putting the skills and knowledge acquired during tertiary education into productive use in the job. This interpretation depicts whether graduates from disadvantaged family backgrounds utilise their human capital efficiently in order to promote economic growth. Second, overqualification can be interpreted as an alternative indicator for individual labour market success since it is related to lower job satisfaction and lower wages. This interpretation is relevant from a social mobility perspective in order to assess whether graduates from disadvantaged family backgrounds reap the benefits of higher education to the same extent as graduates from high status families.

This study contributes to the literature on the determinants of overqualification. Family background has been included in few studies on overqualification determinants, however only as additional control variable (Boll and Lep- 
pin 2013; Fehse and Kerst 2007). In the present study, this relationship is the focal point of the analysis. The main aim is to uncover potential transmission channels mediating the link between family background and overqualification. Depending on the family background, graduates might differ in various characteristics that are potential determinants of overqualification. For instance, (innate) ability and cognitive skills are transmitted within families (Black et al. 2009) and decrease the probability of being overqualified (Büchel and Pollmann-Schult 2004). Similarly, the choice of field of study is affected by family background (Jonsson et al. 2009) and is a crucial determinant of overqualification (Dolton and Vignoles 2000). Using data of the HIS-Graduate Panel 1997, I include a set of proxy variables which account for potential factors mediating the link between social origin and overqualification. These factors include ability and skills, study characteristics, financial capital, social capital, and aspiration. Employing a Blinder-Oaxaca decomposition approach, I then analyse which share of the social overqualification gap can be attributed to differences in these factors. The relative importance of the mediating factors is evaluated by conducting a detailed decomposition of the overqualification gap.

The empirical analysis shows that the risk of overqualification depends on the family background of graduates. Based on parental education (PE), graduates are divided into two groups: They either originate from a family with at least one parent holding a tertiary degree (high PE) or from a family with neither of the parents holding a tertiary degree (low PE). As compared to graduates from low PE families, graduates from high PE families are found to be less likely to hold a job that does not require a tertiary degree, i.e. to be overqualified. The unconditional overqualification gap between graduates from low PE families and graduates from high PE families amounts to 7.4 percentage points. The effect of family background is reduced but remains highly significant if the potential pathways are accounted for in a probit regression. Blinder-Oaxaca decompositions show that roughly $60 \%$ of the social overqualification gap can be attributed to the fact that graduates differ in observable characteristics, i.e. the endowments effect. I find that differences in ability and skills, study characteristics, and social capital are significant mediators of the link between family background and overqualification. The most important pathway is the social difference in the choice of university type and subject pointing to the importance of the horizontal dimension of higher education. In contrast, I find little evidence that financial support or aspiration mediate family background effects on overqualification. However, this result might be influenced by the imprecise measures for these factors.

The remainder of the paper is organised as follows. Section 2 presents the related literature and elaborates on po- tential pathways for family background affecting the risk of overqualification. In Sect. 3 the data are introduced and in Sect. 4 the econometric methodology is described. In Sect. 5 the results are presented and the conclusion is provided in Sect. 6.

\section{Pathways for family background effects}

This section discusses why family background might influence the risk of overqualification and presents potential pathways for the family background effect. Empirical evidence on both the relevant determinants of overqualification as well as their relation to family background is reviewed.

\subsection{Ability and skills}

Skill heterogeneities among workers with the same educational background are likely since human capital also comprises ability and skills that are not acquired during education. Workers could compensate a lack in ability and skills with a higher educational attainment in order to meet their jobs' requirements (Korpi and Tåhlin 2009). Several studies find that individuals with relatively low ability have a higher probability to be overqualified (Chevalier and Lindley 2009). In general, these studies consistently suggest that cognitive skills are an important determinant of overqualification (Green et al. 1999; Quintini 2011). In Germany, individuals with worse school leaving grades or university grades face a higher risk of being overqualified (Büchel and Pollmann-Schult 2004; Fehse and Kerst 2007). Although non-cognitive skills have been found to predict various labour market outcomes (Heckman et al. 2006), studies focusing on non-cognitive skills as determinants of overqualification are scarce. Blázquez and Budría (2012) show that non-cognitive skills significantly reduce the probability of becoming overqualified in Germany. In contrast, Sohn (2010) finds no significant effect for the US.

Family background is a crucial determinant of an individual's ability and skills (Feinstein 2003). Several studies find that cognitive skills of parents and their offspring in adulthood are significantly correlated (Anger and Heineck 2010; Björklund et al. 2010; Black et al. 2009). The same holds for the intergenerational transmission of non-cognitive skills within families (Anger 2012; Grönqvist et al. 2011). The amount of financial resources invested in an individual's human capital is also likely to depend on the social origin (Bourdieu 1983).

Social differences in (innate) ability and skills could maintain a correlation between social origin and overqualification since the probability of being mismatched seems to be affected by cognitive skills and non-cognitive skills. 


\subsection{Study characteristics}

The risk of overqualification has been found to be related to the characteristics of the individual's education. For university graduates, the overqualification rates differ strongly across fields of study (Dolton and Vignoles 2000; Green and McIntosh 2007). Klein (2011) provides evidence that the occupational specificity of a field of study reduces the risk of overqualification. In Germany, the lowest rates of overqualification are observed for the subjects Medicine, Law, and Teaching (Berlingieri and Erdsiek 2012). As shown by Arcidiacono (2004), ability sorting and individual preferences are important drivers of subject choices. Differences in overqualification rates across subjects, therefore, might arise due to self-selection and are not interpretable in a causal manner (Berlingieri and Zierahn 2014). The risk of overqualification also differs across educational institutions. The quality or prestige of the university a worker graduated from has been found to affect the risk of overqualification (Robst 1995; McGuinness 2003). In Germany, individuals who obtained the university entrance certificate can choose between two tracks of tertiary education. They can either enrol at a traditional university or at a university of applied sciences. In general, traditional universities are academically more demanding than the practically oriented study programmes at universities of applied sciences. At the early stage of the career cycle, German graduates from universities of applied sciences face a higher risk of overqualification than graduates from universities (Klein 2011).

Many studies provide empirical evidence that family background is crucially important for educational choices such as the decision to enrol in tertiary education (Lucas 2001). Recently, a growing number of sociological studies analyse how social origin affects the choice of field of study. The results indicate that the subject choice is related to the family's socioeconomic status and parental occupations (Becker et al. 2010; Jonsson et al. 2009). In Germany, the offspring from high status families more often enrol in subjects promising high levels of prestige or economic payoff such as Medicine or Law (Lörz 2012). Social differences tend to be less pronounced in the fields of Engineering or Business \& Economics. The literature has pointed out several pathways for the family background effects on subject choice. In order to avoid downward social mobility, members of the privileged group might be more inclined to choose more promising subjects. Subject choices are also based on considerations on costs and benefits which might depend on the social origin. Furthermore, differences in the school leaving examination grades might contribute to the social stratification in fields of study. Enrollment in some prestigious subjects is restricted by the requirement of school grades better than a certain threshold. In addition, some studies focus on the relevance of occupational reproduction in the context of subject choices (Jonsson et al. 2009; Van de Werfhorst and Luijkx 2010). The intergenerational transmission of occupation-specific knowledge seems to affect the offspring's preferences and interests which are crucial for the subject choice. Family background also might influence the decision whether to enrol in traditional universities or in the more practically oriented universities of applied sciences. Studying at a university of applied sciences might be more appealing for members of the less privileged group for the same reasons that affect the subject choice (Reimer and Pollak 2009). The quality or prestige of the chosen university also might depend on the available financial capital transmitted within families.

Since the risk of overqualification strongly differs across subjects and university type, social stratification in the study programme characteristics might contribute to the association between social origin and overqualification.

\subsection{Capital transmitted within families}

A social gap in the risk of overqualification could also be mediated by the different kinds of capital transmitted within families. The process of finding a job could be directly influenced through the social capital of the parents. Based on their social networks, parents may provide contacts to potential employers. These social connections could be more advantageous for graduates from high status families. For instance, Corak and Piraino (2011) provide evidence for the intergenerational transmission of employers between Canadian fathers and their sons. The probability that sons are working for the same employer as their father increases with the father's earnings and is particularly high among the top income families. Weiss and Klein (2011) analyse how the probability of overqualification is affected by different types of social networks that helped graduates to find their job. Graduates who found their jobs through the agency of their professors or previous internships during the study programme obtain a lower risk of overqualification. In contrast, finding the job through the agency of parents or friends is associated with a higher probability of overqualification.

Furthermore, a family's financial capital might influence the risk of overqualification. Graduates from wealthy families might have the opportunity to search longer for an adequate job than graduates with an adverse family background. Less privileged graduates might be obliged to start working shortly after graduation due to financial constraints resulting in a higher probability to accept an inadequate job. As shown by Berlingieri and Erdsiek (2012), overqualified graduates more often accepted a job in order to avoid unemployment than matched graduates. Baert et al. (2013) point out that being overqualified shortly after graduation 
delays the transition into an adequate job. One explanation could be that overqualification sends an even more negative productivity signal to potential employers than unemployment (McCormick 1990). How familiar graduates are with the high-skilled labour market might also be influenced by the cultural capital provided by the family. The knowledge about job tasks and the functionality of the highskilled labour market could be more profound among children from high status families. More accurate expectations about the selection procedure for high-skilled jobs could improve the performance in recruitment processes and increase the probability to get a job offer.

Social differences in aspiration might affect occupational choices after tertiary education has been completed. Graduates from high status families might try to prevent downward mobility by only accepting jobs requiring tertiary education. In contrast, graduates from low status families already reached the goal of social advancement by obtaining a tertiary degree. They might be less motivated to be in leading positions or to get a high status job (Jacob and Klein 2013). Due to occupational reproduction, graduates might also end up in similar occupations as their parents. For graduates from low status families these jobs are less likely to require a tertiary degree.

\subsection{Discrimination}

Graduates from low status families could be prevented from accessing adequate jobs due to discrimination. A crucial source for discrimination is favouritism which occurs if persons are favoured not because of relevant characteristics but rather because of being a member of a preferred group. In the context of this study, favouritism would occur if recruiters are less likely to pick graduates from low status families out of a group of equally eligible candidates for a high-skilled job. It is important to point out that this behaviour only pictures discrimination if the recruiter's decision is only based on favouring members of high status families but is not due to productivity signals associated with family background. Potential employers could incorporate family background into their selection process of new workers as a signal related to productivity (Jacob and Klein 2013). As pointed out by Erikson and Jonsson (1998), the difference between favouritism and the productivity mechanism is rather subtle.

\section{Data}

\subsection{Data set}

For the empirical analysis data from the first wave of the HIS-Graduate Panel 1997 are employed covering gradu- ates who completed their tertiary education in $1997 .{ }^{1}$ It is a representative nationwide study of tertiary graduates in Germany which surveys individuals one year after graduation. This data set has several advantageous features for my analysis. In comparison to survey data covering the entire work population, focusing the analysis on the policyrelevant group of graduates does not produce small sample sizes. In addition, graduates are observed at the same early stage of the career cycle and face the same overall economic situation. In order to further increase the comparability of graduates, I exclude individuals who were older than 35 years at the time of graduation or who obtained the university entrance certificate abroad. The size of the remaining sample amounts to 3706 graduates.

Overqualification is the main outcome variable in this analysis. I employ a subjective measure for overqualification that is based on self-assessments of the graduates. Graduates were directly asked whether their job usually requires a tertiary education. They are defined to be overqualified if they indicate that their job usually does not require a tertiary degree. Since this measure relies on the workers' self-assessment, it is sensitive to potential differences in the individuals' perception of job requirements (Barone and Ortiz 2011). Estimates of the family background effect on overqualification would be biased if actually identical job requirements were assessed differently by graduates who originate from either low or high status families. Therefore, I have to assume that the assessment of job requirements does not systematically differ between both groups of graduates. As pointed out in the literature, the subjective measure of overqualification has the main advantage that it captures specific job characteristics that only the job holder can assess and, thus, is not based on information aggregated at any occupational level (Hartog 2000). ${ }^{2}$

The central explanatory variable of this study is the social origin of graduates which is measured in terms of parental education (PE). In particular, I use the information whether at least one parent has completed tertiary education. Gradu-

\footnotetext{
${ }^{1}$ Hochschul-Informations-System (HIS), Hannover (2007): HISGraduate Panel 1997. GESIS Data Archive, Köln. ZA4272 Data File Version 1.0.0, dx.doi.org/10.4232/1.4272.

2 In addition to the subjective indicator, two objective methods for measuring required education have been employed in the literature. First, the assignment of required education to occupations based on the evaluation of job analysts (JA approach). Second, the realized matches (RM) approach focusing on the distribution of educational qualifications possessed by workers within an occupation. The main drawback of the RM approach is that it measures the endogenous allocation of workers to jobs driven by demand and supply forces rather than the genuine job requirements. In contrast, the measures of the JA approach are based on the technology of the job yielding an objective evaluation of requirements. However, heterogeneities of jobs within occupational codes are ignored and JA indicators are not available for most countries, e.g. Germany. Hartog (2000) provides a detailed discussion on overqualification measures.
} 
ates are divided into two groups: They either originate from a family with at least one parent holding a tertiary degree (high PE) or from a family with neither of the parents holding a tertiary degree (low PE). An education-based measure of family background is likely to be correlated with other, unobserved aspects of social origin, such as parents' ability, preferences or support. Therefore, parental education serves as a general proxy for the educational, social and economic background of graduates.

The aim of this study is to uncover which channels contribute to the social gap in the risk of overqualification. Employing a rich data set, I thus include the following proxy variables for the aforementioned potential mediators. The potential mediating channel of social differences in ability and skills is accounted for by including school leaving examination grades and university grades. ${ }^{3}$ Grades can take decimal values within the range of 1 to 4 , with higher grades indicating better achievements. Since the procedures of the school leaving examination differ across the 16 federal states in Germany, school grades are standardised within federal states. University grades are standardised within fields of study and university types in order to account for differences in the distribution of grades.

Differences in the study programme characteristics are observed in terms of field of study, university type and study duration. The subject groups Medicine \& Law, and Teaching can solely be studied at universities, whereas the remaining subjects can be studied at either universities or universities of applied sciences. The latter subjects are divided into three groups, namely Science, Technology, Engineering, and Mathematics (STEM subjects), Business \& Economics, and Social \& Cultural Sciences. Dummy variables are generated for each combination of subject group and type of university (university vs. university of applied sciences). Study duration (in semesters) is standardised within subjects and university types since average study durations vary across subjects and university types.

Information on job search channels is employed to account for differences in social capital. Respondents indicated whether they found their current job through the guidance of their parents or friends. If high-skilled parents have better connections to potential employers, this search channel could be more profitable for graduates from high PE families. Further search channels include connections that have been established during a previous internship or other jobs the graduate has had before or during the study.

Financial capital is a crucial part of the properties that characterise high status families. Unfortunately, the data set does not contain a direct question concerning a family's

\footnotetext{
${ }^{3}$ Although grades are surely an imperfect proxy for ability, previous research shows that cognitive as well as non-cognitive skills are relevant predictors of grades (Almlund et al. 2011; Poropat 2009).
}

financial capital such as parental earnings. Therefore, a set of 3 proxy variables are employed. First, I include the information to what extent graduates financed their costs of living during the study by own work or by parental support. Although the observed shares result from graduates' choices, they could proxy for parental financial capital. The offspring from poorer families, for instance, are expected to be more often constrained to work during the study. This is also the rationale of the second proxy variable, where respondents indicate if their job during study was related or unrelated to their subject. If working is necessary for financing the study, it may be more likely that jobs are taken that are unrelated to the subject. The third proxy for financial capital covers information on the graduates' regional mobility. The respondents indicate the distance between working place and native place. The rationale of this proxy is that moving or commuting over a long distance could be encouraged by parental financial support.

Graduates whose parents are not highly educated already achieved social advancement in terms of educational attainment. Low PE graduates, therefore, might have lower aspirations concerning subsequent labour market success than high PE graduates. In order to control for social differences in aspiration and career orientation, I employ two sets of questions. First, respondents were asked about their future career goals. They had to indicate whether they plan to perform better than the average, to fully exploit their own potential, or to fill a leading position. Second, respondents were asked which actions they have already undertaken to improve their career prospects. The items include showing a high commitment to the job, taking additional courses during the study programme, gaining experiences abroad, being regionally mobile, and establishing social networks. ${ }^{4}$

Finally, I include a gender dummy and control variables for age, marriage, and parenthood at the time of the survey (one year after graduation).

\subsection{Descriptive statistics}

Descriptive statistics for the estimation sample are provided in Table 1 . One year after graduation $20 \%$ of the respondents are overqualified, i.e. they hold jobs that usually do not require a tertiary education. $46 \%$ of the graduates originate from a high PE family, i.e. at least one parent holds a tertiary degree. With a share of $25 \%$, most respondents graduated in STEM subjects at traditional universities.

Table 2 presents the differences in the mean values depending on the family background. Column 1 presents the means for graduates from low PE families, whose

\footnotetext{
${ }^{4}$ The two items concerning experiences abroad and mobility may not only proxy for career orientation but also depend on the financial capital of the parents.
} 
Tab. 1 Descriptive Statistics

\begin{tabular}{lllll}
\hline & Mean & SD & Min & Max \\
\hline Overqualification & 0.201 & 0.401 & 0 & 1 \\
High PE & & & \\
(Pre-)Study characteristics: & & & & \\
Vocational education $^{\text {School grade }}$ & 0.461 & 0.499 & 0 & 1 \\
University grade $^{\mathrm{c}}$ & 0.000 & 0.998 & -3.16 & 2.53 \\
Duration of study $^{\mathrm{c}}$ & 0.000 & 0.998 & -4.12 & 2.42 \\
Univ. of applied sciences $^{\text {(UAS) }}$ & 0.000 & 0.998 & -2.54 & 6.29 \\
& 0.253 & 0.435 & 0 & 1
\end{tabular}

(UAS)

University types, Subjects:

\begin{tabular}{|c|c|c|c|c|}
\hline Univ.: Medicine \& Law & 0.111 & 0.314 & 0 & 1 \\
\hline Univ.: Teaching & 0.112 & 0.315 & 0 & 1 \\
\hline Univ.: STEM Subjects & 0.247 & 0.431 & 0 & 1 \\
\hline UAS: STEM Subjects & 0.172 & 0.377 & 0 & 1 \\
\hline Univ.: Bus \& Econ & 0.145 & 0.352 & 0 & 1 \\
\hline UAS: Bus \& Econ & 0.046 & 0.209 & 0 & 1 \\
\hline Univ.: Soc \& Cult Science & 0.133 & 0.340 & 0 & 1 \\
\hline UAS: Soc \& Cult Science & 0.035 & 0.184 & 0 & 1 \\
\hline \multicolumn{5}{|l|}{ Job found through: } \\
\hline Agency of parents/friends & 0.077 & 0.267 & 0 & 1 \\
\hline Job before studying & 0.048 & 0.214 & 0 & 1 \\
\hline Job while studying & 0.126 & 0.332 & 0 & 1 \\
\hline Internship & 0.162 & 0.369 & 0 & 1 \\
\hline \multicolumn{5}{|l|}{ Worked during study: } \\
\hline Yes: related to subject & 0.569 & 0.495 & 0 & 1 \\
\hline Yes: not related to subject & 0.189 & 0.392 & 0 & 1 \\
\hline Not worked during study & 0.242 & 0.428 & 0 & 1 \\
\hline \multicolumn{5}{|l|}{ Study was financed by: } \\
\hline Own work (in \%) & 28.453 & 22.538 & 0 & 99 \\
\hline Parental support (in \%) & 44.766 & 31.489 & 0 & 99 \\
\hline \multicolumn{5}{|l|}{$\begin{array}{l}\text { Distance work and native } \\
\text { place: }\end{array}$} \\
\hline Less than $50 \mathrm{~km}$ & 0.470 & 0.499 & 0 & 1 \\
\hline Between $50 \mathrm{~km}$ and $100 \mathrm{~km}$ & 0.146 & 0.353 & 0 & 1 \\
\hline More than $100 \mathrm{~km}$ & 0.385 & 0.487 & 0 & 1 \\
\hline \multicolumn{5}{|l|}{ Improve career prospects: } \\
\hline Commitment to the job & 0.433 & 0.496 & 0 & 1 \\
\hline Gained experience abroad & 0.313 & 0.464 & 0 & 1 \\
\hline Established social networks & 0.406 & 0.491 & 0 & 1 \\
\hline Have been mobile & 0.300 & 0.458 & 0 & 1 \\
\hline Attended additional courses & 0.415 & 0.493 & 0 & 1 \\
\hline \multicolumn{5}{|l|}{ Future goals: } \\
\hline Above-average performance & 0.685 & 0.465 & 0 & 1 \\
\hline Fully exploit own potential & 0.801 & 0.399 & 0 & 1 \\
\hline Fill a leading position & 0.547 & 0.498 & 0 & 1 \\
\hline Observations & 3706 & & & \\
\hline
\end{tabular}

${ }^{a}$ High Parental Education (PE) takes value one if at least one parent has a tertiary degree and zero otherwise ${ }^{b}$ Standardised within federal states ${ }^{\mathrm{c}}$ Standardised within subjects and university types. Source: HIS-Graduate Panel 1997.
Tab. 2 Descriptive Statistics by Family Background

\begin{tabular}{|c|c|c|c|}
\hline & \multirow{2}{*}{$\begin{array}{l}\text { Low PE } \\
\text { Mean }\end{array}$} & \multicolumn{2}{|l|}{ High PE } \\
\hline & & Mean & Diff. \\
\hline \multicolumn{4}{|l|}{ Dependent variable: } \\
\hline Overqualification & 0.235 & 0.161 & $0.074 * * *$ \\
\hline \multicolumn{4}{|l|}{ (Pre-)Study characteristics: } \\
\hline Vocational education & 0.468 & 0.263 & $0.205^{* * *}$ \\
\hline School grade ${ }^{a}$ & -0.116 & 0.136 & $-0.252^{* * *}$ \\
\hline University grade ${ }^{b}$ & -0.038 & 0.044 & $-0.082 * *$ \\
\hline Duration of study ${ }^{b}$ & -0.009 & 0.011 & -0.020 \\
\hline $\begin{array}{l}\text { Univ. of applied sciences } \\
\text { (UAS) }\end{array}$ & 0.342 & 0.148 & $0.194^{* * *}$ \\
\hline \multicolumn{4}{|l|}{ University types, Subjects: } \\
\hline Univ.: Medicine \& Law & 0.078 & 0.149 & $-0.071 * * *$ \\
\hline Univ.: Teaching & 0.101 & 0.124 & $-0.023^{* *}$ \\
\hline Univ.: STEM Subjects & 0.207 & 0.293 & $-0.086^{* * *}$ \\
\hline UAS: STEM Subjects & 0.237 & 0.095 & $0.143^{* * *}$ \\
\hline Univ.: Bus \& Econ & 0.150 & 0.139 & 0.012 \\
\hline UAS: Bus \& Econ & 0.063 & 0.026 & $0.037^{* * *}$ \\
\hline Univ.: Soc \& Cult Science & 0.121 & 0.147 & $-0.026^{* *}$ \\
\hline UAS: Soc \& Cult Science & 0.042 & 0.028 & $0.014^{* *}$ \\
\hline \multicolumn{4}{|l|}{ Job found through: } \\
\hline Agency of parents/friends & 0.076 & 0.079 & -0.003 \\
\hline Job before studying & 0.063 & 0.030 & $0.033^{* * *}$ \\
\hline Job while studying & 0.136 & 0.115 & $0.020 *$ \\
\hline Internship & 0.160 & 0.164 & -0.004 \\
\hline \multicolumn{4}{|l|}{ Worked during study: } \\
\hline Yes: related to subject & 0.560 & 0.580 & -0.020 \\
\hline Yes: not related to subject & 0.223 & 0.150 & $0.073^{* * *}$ \\
\hline Not worked during study & 0.217 & 0.270 & $-0.053^{* * *}$ \\
\hline \multicolumn{4}{|l|}{ Study was financed by: } \\
\hline Own work (in \%) & 32.243 & 24.025 & $8.218^{* * *}$ \\
\hline Parental support (in \%) & 33.948 & 57.407 & $-23.46^{* * *}$ \\
\hline \multicolumn{4}{|l|}{$\begin{array}{l}\text { Distance work and native } \\
\text { place: }\end{array}$} \\
\hline Less than $50 \mathrm{~km}$ & 0.492 & 0.444 & $0.048^{* * *}$ \\
\hline Between $50 \mathrm{~km}$ and $100 \mathrm{~km}$ & 0.162 & 0.126 & $0.036^{* * *}$ \\
\hline More than $100 \mathrm{~km}$ & 0.346 & 0.430 & $-0.084^{* * *}$ \\
\hline \multicolumn{4}{|l|}{ Improve career prospects: } \\
\hline Commitment to the job & 0.435 & 0.431 & 0.004 \\
\hline Gained experience abroad & 0.254 & 0.381 & $-0.127^{* * *}$ \\
\hline Established social networks & 0.393 & 0.422 & $-0.030^{*}$ \\
\hline Have been mobile & 0.295 & 0.305 & -0.011 \\
\hline Attended additional courses & 0.409 & 0.422 & -0.013 \\
\hline \multicolumn{4}{|l|}{ Future goals } \\
\hline Above-average performance & 0.686 & 0.685 & 0.001 \\
\hline Fully exploit own potential & 0.798 & 0.804 & -0.006 \\
\hline Fill a leading position & 0.553 & 0.541 & 0.013 \\
\hline Observations & 1997 & 1709 & 3706 \\
\hline
\end{tabular}

${ }^{\mathrm{a}}$ Standardised within federal states ${ }^{\mathrm{b}}$ Standardised within subjects and university types; Significant at $1 \%{ }^{* * *}$, significant at $5 \%{ }^{* *}$, significant at 10\% *. Source: HIS-Graduate Panel 1997. 
parents do not hold a tertiary degree, and column 2 presents the means for graduates from high PE families. A share of $16.1 \%$ of the high PE graduates is overqualified whereas $23.5 \%$ of the graduates from low PE families are overqualified. ${ }^{5}$ Column 3 shows that the mean difference of 7.4 percentage points is significantly different from zero at the 1 percent level.

The two groups of graduates are highly heterogenous with respect to observable characteristics. Graduates from high PE families have better school leaving examination grades and finished their study programme with better university grades than low PE graduates. ${ }^{6}$ The choice of the university type and field of study also differs strongly between both groups of graduates. While $34 \%$ of the respondents from low PE families graduated from a university of applied science, the share for high PE graduates amounts to only $15 \%$. Social differences in the choice of university type remain significant if subjects are presented separately. Except for the subject group Business \& Economics, low PE graduates study significantly less often at traditional universities than high PE graduates. For instance, Medicine \& Law is studied nearly twice as often by high PE graduates $(15 \%)$ than by low PE graduates $(8 \%)$.

The job search channels differ in some aspects. Low PE graduates more often found their job through jobs they had before studying $(6 \%)$ or during the study $(14 \%)$. This finding corresponds to the fact that the share of respondents who completed a vocational education before entering the study programme is higher among low PE graduates. There are no significant differences in the share of graduates finding a job through the agency of parents/friends $(8 \%)$ or an internship (16\%).

Concerning the proxies for the families' financial capital, I find that during the study programme low PE graduates more often worked in jobs not related to their subject $(22 \%)$. Low PE graduates financed a share of $32 \%$ of their costs of living during the study programme by own work. In contrast, earnings from own work covered only $24 \%$ for high PE graduates. The share of costs of living financed by parental support was significantly higher for high PE graduates $(57 \%)$ than for low PE graduates $(34 \%)$. High $\mathrm{PE}$ graduates have been more mobile than low PE graduates since they are more likely to work more than 100 kilometers away from the native place $(43 \%)$.

\footnotetext{
5 With the data at hand, little evidence for social differences concerning the selection into employment is found. At the time of the survey, $2.8 \%$ of high PE graduates and $3.0 \%$ of graduates from low PE families have been unemployed.

${ }^{6}$ Social differences in university grades cannot be driven by self-selection into subjects with a higher level of average grades since university grades are standardised within university type and subject.
}

I find little evidence for social differences in the proxy variables for career orientation and aspiration. For instance, $43 \%$ of both groups of graduates indicated that they have shown high commitment to the job in order to improve career prospects and $55 \%$ indicated that they have the future goal of filling a leading position. However, the share of graduates who gained experiences abroad is significantly higher among high PE graduates (38\%) than among low PE graduates $(25 \%)$.

\section{Methodology}

As shown in the descriptive statistics, overqualification is more prevalent among graduates from low PE families than among graduates from high PE families. The empirical analysis now focuses on the question which of the aforementioned pathways contribute to the social overqualification gap.

In a first step, it is tested whether the family background effect is robust against the inclusion of the potential mediating variables. Conducting probit regressions, the effects of family background and the mediating factors on the probability to be overqualified one year after graduation are estimated. For graduate $i$, the relationship is specified as:

$$
\begin{aligned}
& \operatorname{Pr}\left[\text { Overqualification }_{i}=1 \mid \text { High_PE }_{i}, \mathbf{X}_{\mathbf{i}}\right] \\
& =\Phi\left(\alpha+\beta_{\text {High_PE }} H i g h \_P E_{i}+\boldsymbol{\beta}_{\mathbf{X}} \mathbf{X}_{\mathbf{i}}\right)
\end{aligned}
$$

with $\Phi(\cdot)$ representing the cumulative normal distribution function. The binary variable Overqualification takes the value one if a graduate works in a job that does not require a tertiary education and zero otherwise. Family background is measured by the binary variable High PE taking the value one if at least one parent holds a tertiary degree and zero if parents do not hold a tertiary degree. All aforementioned control variables are included in matrix $\mathbf{X}$.

In the second step, a decomposition analysis is applied to reveal how differences in observable characteristics contribute to the social overqualification gap. For this purpose, I employ the Blinder-Oaxaca decomposition method for mean outcome differences (Blinder 1973; Oaxaca 1973). In a linear model, the raw differential in the continuous outcome variable $\mathrm{Y}$ between two groups $\mathrm{L}$ and $\mathrm{H}$ can be expressed in two ways:

$\bar{Y}_{L}-\bar{Y}_{H}=\left(\bar{X}_{L}-\bar{X}_{H}\right) \beta_{L}+\bar{X}_{H}\left(\beta_{L}-\beta_{H}\right)$,

$\bar{Y}_{L}-\bar{Y}_{H}=\left(\bar{X}_{L}-\bar{X}_{H}\right) \beta_{H}+\bar{X}_{L}\left(\beta_{L}-\beta_{H}\right)$,

where $\bar{X}_{j}$ is a row vector comprising average values of the independent variables and $\beta_{j}$ is a vector of coefficient est- 
imates obtained by OLS regressions for group $j=L, H{ }^{7}$ The first part on the right hand side of both equations is the explained part of the raw gap that can be attributed to differences in observable characteristics, i.e. the endowments effects. The second term on the right hand side indicates which share of the gap is due to group differences in the estimated coefficients. This unexplained part also picks up the share of the raw differential due to differences in unobservable characteristics, i.e. unobserved heterogeneity between groups $\mathrm{L}$ and $\mathrm{H}$. The unexplained part can thus not be interpreted as a single measure for discrimination such that the same bundle of characteristics is less valuable for one group only because of group membership.

Equations (2) and (3) differ in terms of the weights used for the evaluation of the endowments effect. The selection of the weighting scheme hinges on the expectation whether members of group L or members of group $\mathrm{H}$ are being discriminated. Optimally, the nondiscriminatory coefficients should be used but these are unknown and have to be approximated. If it is assumed, for instance, that group $\mathrm{H}$ is being discriminated, the endowments effect is evaluated by the coefficients of group $\mathrm{L}\left(\beta_{L}\right)$ (Eq. 2). ${ }^{8}$

Since the outcome variable in the present study is binary, I employ the methodology by Yun (2004) enabling Blinder-Oaxaca decompositions for non-linear models. Using this methodology, the social overqualification gap can be decomposed into the endowments effect and coefficients effect at the aggregate level. Furthermore, the methodology is suited to indicate the contribution of each variable to the raw differential, i.e. to compute the detailed decomposition. I will use the detailed decomposition to analyse which pathways are particularly relevant for generating the social overqualification gap.

\section{Results}

\subsection{Probit results}

Results from probit estimations of overqualification on family background and relevant control variables are provided in Table 3. The marginal effect of originating from a high $\mathrm{PE}$ family is significant if socio-demographic controls and proxies for ability are included in the probit model (specification 1). The likelihood of being overqualified is 6.2 per-

\footnotetext{
7 The auxiliary regressions for groups $\mathrm{L}$ and $\mathrm{H}$ are: $Y_{L}=F\left(X_{L} \beta_{L}\right)$ and $Y_{H}=F\left(X_{H} \beta_{H}\right)$

${ }^{8}$ In many cases, it remains unclear which group is solely discriminated leading to an "index-number problem" (Oaxaca 1973). Since the choice of the weight influences the segmentation into the explained and unexplained part, researchers often present decomposition results for both weighting schemes or use coefficients from a pooled regression (Neumark 1988).
}

centage points lower for graduates whose parents obtained higher education than for graduates from low PE families. Better school leaving examination grades and university grades significantly reduce the probability of being overqualified. Since university grades are standardised within subjects and university types, the results suggest that the probability to be overqualified reduces by 5 percentage points if university grades increase by one standard deviation.

In specification 2, further study characteristics are included in the model. The coefficient of family background decreases but remains highly significant. While the effect of university grades hardly changes, the effect of school grades diminishes. The favourable effect of good school grades on the risk of overqualification, therefore, might work through the selection into subjects promising a good transition into the labour market. University grades seem to be more important to potential employers who might use this information as a signal for job related skills. Similarly, the significant and positive coefficient of standardised study duration could indicate that an above-average study duration sends a negative signal regarding a graduate's ability or motivation. The incidence of overqualification is found to strongly differ across subjects. Compared to the reference group of Social \& Cultural Sciences at traditional universities, graduates in Medicine \& Law obtain a 20.5 percentage points lower probability to be overqualified. Only Business \& Economics graduates from universities of applied sciences do not obtain a significantly lower probability of overqualification than the reference group. Due to selfselection into subjects, however, these effects can not be interpreted in a causal manner.

Specification 3 includes the full set of observable characteristics that could mediate the relationship between family background and overqualification. The family background effect reduces but remains significant. The results indicate that the probability to be overqualified is 3.3 percentage points lower for graduates from high PE families even if grades, study characteristics and the following mediating factors are accounted for.

Information on a graduate's social capital is included in terms of job search channels. Finding the current job through the agency of parents/friends, a job before studying, or a job while studying increases the probability to be overqualified. Since jobs held before or during the study usually do not require tertiary education, these social networks seem to hamper the transition into a matching job. In contrast, social connections based on internships support a good start of the career. Finding a job through an internship is associated with a reduction in overqualification by 6.9 percentage points.

The financial capital of families is measured through working experience during the study, the parents' finan- 
Tab. 3 Probit Regressions, Overqualification

Dependent variable: Overqualification

(1)

High PE
(Pre-)Study characteristics:

Vocational education

School grade

University grade

Duration of study

University types, Subjects. ${ }^{\mathrm{b}}$

Univ.: Medicine \& Law

Univ.: Teaching

Univ.: STEM Subjects

UAS: STEM Subjects

Univ.: Bus \& Econ

UAS: Bus \& Econ

UAS: Soc \& Cult Science

Job found through:

Agency of parents/friends

Job before studying

Job while studying

Internship

Worked during study: ${ }^{c}$

Yes: related to subject

Yes: not related to subject

Study was financed by:

Own work (in \%)

Parental support (in \%)

Distance work and native place: ${ }^{\mathrm{d}}$

Between $50 \mathrm{~km}$ and $100 \mathrm{~km}$

More than $100 \mathrm{~km}$

Improve career prospects:

Commitment to the job

Gained experience abroad

Established social networks

Have been mobile

Attended additional courses

Future goals:

Fully exploit own potential

Fill a leading position

Socio-demographics ${ }^{\text {e }}$

Observations

Pseudo $R^{2}$
Above-average performance

$-0.062^{* * *} \quad(0.013)$

\begin{tabular}{|c|c|c|c|c|c|}
\hline & & 0.021 & $(0.017)$ & 0.011 & $(0.017)$ \\
\hline$-0.023^{* * *}$ & $(0.007)$ & -0.010 & $(0.007)$ & -0.004 & $(0.007)$ \\
\hline \multirow[t]{27}{*}{$-0.050^{* * *}$} & $(0.007)$ & $-0.053^{* * *}$ & $(0.007)$ & $-0.041^{* * *}$ & $(0.007)$ \\
\hline & & $0.017^{* *}$ & $(0.007)$ & $0.014^{* *}$ & $(0.007)$ \\
\hline & & $-0.205^{* * *}$ & $(0.008)$ & $-0.194 * * *$ & $(0.008)$ \\
\hline & & $-0.136^{* * *}$ & $(0.013)$ & $-0.134 * * *$ & $(0.012)$ \\
\hline & & $-0.164 * * *$ & $(0.014)$ & $-0.146^{* * *}$ & $(0.014)$ \\
\hline & & $-0.103^{* * *}$ & $(0.017)$ & $-0.091 * * *$ & $(0.017)$ \\
\hline & & $-0.038^{* *}$ & $(0.019)$ & -0.020 & $(0.020)$ \\
\hline & & 0.019 & $(0.032)$ & 0.031 & $(0.033)$ \\
\hline & & $-0.085^{* * *}$ & $(0.023)$ & $-0.078^{* * *}$ & $(0.023)$ \\
\hline & & & & $0.143^{* * *}$ & $(0.029)$ \\
\hline & & & & $0.109^{* * *}$ & $(0.035)$ \\
\hline & & & & $0.086 * * *$ & $(0.022)$ \\
\hline & & & & $-0.069^{* * *}$ & $(0.015)$ \\
\hline & & & & $-0.042 * *$ & $(0.018)$ \\
\hline & & & & -0.012 & $(0.019)$ \\
\hline & & & & $0.001 *$ & $(0.000)$ \\
\hline & & & & 0.000 & $(0.000)$ \\
\hline & & & & $-0.034^{* *}$ & $(0.016)$ \\
\hline & & & & $-0.051^{* * *}$ & $(0.014)$ \\
\hline & & & & $-0.031 * *$ & $(0.013)$ \\
\hline & & & & $-0.035^{* * *}$ & $(0.014)$ \\
\hline & & & & 0.006 & $(0.013)$ \\
\hline & & & & $-0.027^{*}$ & $(0.014)$ \\
\hline & & & & 0.011 & $(0.013)$ \\
\hline & & & & $-0.029^{* *}$ & $(0.014)$ \\
\hline & & & & 0.019 & $(0.015)$ \\
\hline & & & & -0.002 & $(0.013)$ \\
\hline Yes & & Yes & & Yes & \\
\hline 3706 & & 3706 & & 3706 & \\
\hline 0.047 & & 0.126 & & 0.166 & \\
\hline
\end{tabular}

Probit estimations; Marginal effects (at the average); Standard errors in parentheses a Takes value one if at least one parent has a tertiary degree and zero otherwise ${ }^{\mathrm{b}}$ Reference: Univ: Social \& Cultural Sciences ${ }^{\mathrm{c}}$ Reference: Not worked during study ${ }^{\mathrm{d}}$ Reference: Less than $50 \mathrm{~km}{ }^{\mathrm{e}}$ Sociodemographic controls include age and dummies for gender, being married, and having children; Significant at $1 \%^{* * *}$, significant at $5 \%{ }^{* *}$, significant at $10 \% *$.
(2)

(3)

$-0.041^{* * *} \quad(0.013) \quad-0.033^{* *} \quad(0.014)$

$0.143^{* * *}$

$0.086^{* * *}$

$-0.042^{* *}$

$0.001^{*}$

$-0.034^{* *}$

-0.031 *

0.006

$-0.027$

$-0.029^{* *}$

(0.015)

$-0.002$

3706

0.166 
cial support and regional mobility. Graduates who worked in a subject-related job during the study are significantly less likely to be overqualified than graduates who did not work during the study. No favourable effect is found for working in jobs unrelated to the subject. The probability to be overqualified increases with the share of costs of living during the study that was financed by own work. But no significant effect is found for the share that was covered by parental support. Regional mobility is related to a lower risk of overqualification. Graduates whose working place is more than 50 kilometers away from their native place are significantly less likely to be overqualified. Of course, this effect cannot be interpreted in a causal way since the decision to move or commute itself is probably determined by the job quality. With respect to the focus of the analysis, however, it could be relevant if social differences in the graduates' regional mobility contribute to the overqualification gap.

Some of the proxies for career orientation and aspiration are significantly related to overqualification. The probability to be overqualified is roughly 3 percentage points lower for graduates who indicated that they showed commitment to the job, gained experiences abroad, or were regionally mobile in order to improve their career prospects. Moreover, the share of overqualification is 2.9 percentage points lower among graduates who have the future goal to perform above-average in their job.

The robust family background effect in specification 3 could be the result of both unobserved heterogeneity and discrimination. An important source for unobserved heterogeneity might be that the available proxy variables measure the mediating factors for family background effects imprecisely. For instance, school grades and university grades are used as proxies for ability and skills. However, social differences in specific skills like numeracy or literacy are not observed. A further important component of an individual's human capital are non-cognitive skills which predict various labour market outcomes. The literature on human capital acquisition generally concludes that the offspring of wealthy families have higher non-cognitive skills. Therefore, including a proxy for non-cognitive skills could reduce the conditional correlation between social origin and overqualification. The present study, however, focuses on a highly selective group of individuals who completed tertiary education. Whether social differences in non-cognitive skills exist among the highly educated respondents in the sample is unclear. Graduates originating from low PE families might only have been able to complete higher education because they compensated the less favourable parental support by higher non-cognitive skills.

Proxy variables for the different kinds of capital transmitted within families might also be imprecise. For instance, I cannot observe whether graduates accepted a job offer because of financial constraints due to low financial capital of the parents. Furthermore, I cannot control for social differences in cultural capital. Graduates from high PE families might be more familiar with hiring procedures and the functionality of the high-skilled labour market. Graduates might also differ in terms of transmitted preferences and opinions that lower the risk of overqualification. Finally, it is likely that my measures for career orientation and aspiration cannot account for the entirety of this phenomena. For instance, some career choices might be the result of unconscious decision processes related to innate aspiration.

The family background effect could also be attributed to preferences of potential employers. Recruiters could use the family background as a signal for ability and skills. Furthermore, they could value individual characteristics differently depending on social origin of the applicants. The latter case implies discrimination if recruiters favour applicants from high PE families without any other reason than group membership. As a consequence, graduates exhibiting the same characteristics could differ in the number and quality of jobs they get offered.

\subsection{Decomposition results}

Employing a decomposition analysis, individual characteristics are identified that mediate the effect of family background on the probability to be overqualified. ${ }^{9}$ In a first step, the group specific coefficients are estimated by running probit regressions separately for graduates from low PE families (specification 1) and high PE families (specification 2) as presented in Table 4. The results show similar effects of university grades, study characteristics and job search channels for both groups of graduates. The significant increase in the overqualification risk due to finding the job through the guidance of parents/friends is not statistically different between low PE graduates (13 percentage points) and high PE graduates (15 percentage points).

Holding a subject-related job during study and financing the study through own work is significantly correlated with overqualification solely for low PE graduates. Gaining experiences abroad reduces the risk of overqualification for both groups, while the effects of the remaining strategies to improve career prospects depend on social origin. High PE graduates who have the future goal of above-average performance obtain a lower overqualification risk, while overqualification is more likely among those who plan to fully exploit their own potential. The latter effect may result

\footnotetext{
9 Decomposition results were computed in Stata employing the "Oaxaca" command (Jann 2008) incorporating the non-linear decomposition proposed by Yun (2004). As a robustness test, the analysis has also been conducted using the non-linear extension proposed by Fairlie (2005). The results are not qualitatively sensitive to the choice of methodology.
} 
Tab. 4 Probit Regressions by Family Background, Overqualification
Dependent variable: Overqualification Low PE

High PE

(1)

(2)

(Pre-)Study characteristics:

Vocational education

0.003

$-0.012$

$(0.025)$

School grade

$-0.041^{* * *}$

(0.011)

University grade

Duration of study

0.020 *

$(0.010)$

University types, Subjects: ${ }^{\mathrm{a}}$

Univ.: Medicine \& Law

Univ.: Teaching

Univ.: STEM Subjects

UAS: STEM Subjects

Univ.: Bus \& Econ

UAS: Bus \& Econ

UAS: Soc \& Cult Science

Job found through:

Agency of parents/friends

Job before studying

Job while studying

Internship

Worked during study:

Yes: related to subject

Yes: not related to subject

Study was financed by:

Own work (in \%)

$-0.216^{* * *} \quad(0.013)$

$-0.144^{* * *} \quad(0.022)$

$-0.147^{* * *} \quad(0.024)$

$-0.081^{* * *} \quad(0.030)$

0.024

(0.035)

0.085

(0.052)

$-0.117^{* * *}$

(0.032)

$0.129^{* * *}$

$(0.041)$

0.086 *

$(0.045)$

$0.102^{* * *}$

$(0.033)$

$-0.088^{* * *}$

(0.024)

$-0.081^{* * *}$

$(0.027)$

$-0.043$

(0.028)

$0.001^{* *}$

$(0.000)$

(0.000)

$-0.000$

(0.000)

Parental support (in \%)

Distance work and native

place: ${ }^{\mathrm{c}}$

Between $50 \mathrm{~km}$ and $100 \mathrm{~km}$

$-0.073^{* * *} \quad(0.022)$

(0.021)

0.017

$-0.035^{* *}$

(0.025)

$-0.073^{* * *}$

(0.020)

$-0.016$

$(0.022)$

Commitment to the job

-0.038 *

$(0.020)$

Established social networks

$-0.012$

$(0.022)$

Have been mobile

$-0.044^{* *}$

(0.020)

Future goals:

Above-average performance

Fully exploit own potential

Fill a leading position

Socio-demographics ${ }^{d}$

Observations

Pseudo $R^{2}$

(0.021)

$(0.024)$

(0.020)

$\begin{array}{ll}-0.023 & (0.021) \\ 0.001 & (0.024) \\ 0.007 & (0.020)\end{array}$

Yes

1997

0.150

$-0.041^{* *}$

-0.030 *

(0.016)

0.030 *

(0.016)

$-0.009$

(0.018)

0.017

(0.016)

Probit estimations; Marginal effects (at the average); Standard errors in parentheses a Reference: Univ: Social \& Cultural Sciences ${ }^{b}$ Reference: Not worked during study ${ }^{\mathrm{c}}$ Reference: Less than $50 \mathrm{~km}{ }^{\mathrm{d}}$ Sociodemographic controls include age and dummies for gender, being married, and having children; Significant at $1 \% * * *$, significant at $5 \%{ }^{* *}$, significant at $10 \% *$. 
Tab. 5 Decomposition of the Overqualification Gap, Weighted by Coefficients of Low PE Graduates $\left(\beta_{L}\right)$

\begin{tabular}{llllll}
\hline & Coef. & Std. Err. & $P>|z|$ & $\begin{array}{l}\text { \% of Total } \\
\text { gap }\end{array}$ & $\begin{array}{l}\text { \% of Ex- } \\
\text { plained part }\end{array}$ \\
\hline Low PE & 0.235 & 0.009 & 0.000 & & \\
High PE & 0.161 & 0.009 & 0.000 & & \\
Total overqualification gap & 0.074 & 0.013 & 0.000 & 60.6 & \\
Explained part & 0.045 & 0.009 & 0.000 & 39.4 & \\
Unexplained part & 0.029 & 0.013 & 0.026 & 5.4 \\
Contribution to explained part & & & & 6.1 \\
Vocational education & 0.001 & 0.004 & 0.893 & -0.7 \\
School grade & 0.002 & 0.002 & 0.280 & 66.4 \\
University grade & 0.003 & 0.001 & 0.035 & 8.1 \\
Study duration & 0.000 & 0.001 & 0.556 & -3.0 \\
University types, Subjects & 0.030 & 0.006 & 0.000 & -0.3 \\
How job was found & 0.004 & 0.002 & 0.051 & 6.4 \\
Worked during study & -0.001 & 0.002 & 0.442 & 10.2 \\
Financing of study & 0.000 & 0.007 & 0.983 & & 0.1 \\
Dist work, native place & 0.003 & 0.002 & 0.119 & & 0.1 \\
Improve career prospects & 0.005 & 0.002 & 0.063 & \\
Future goals & 0.000 & 0.000 & 0.885 & \\
Socio-demographics & 0.000 & 0.003 & 0.986 & \\
\hline Probit & & & \\
\end{tabular}

Probit decomposition computed in Stata employing the procedure by Jann (2008); Explained part evaluated by coefficients of graduates from low PE families. from reversed simultaneity because overqualified workers might set this future goal as a reaction to the current underutilization of skills.

Based on the presented auxiliary probit regressions, the social overqualification gap can be decomposed into two parts that are explained or unexplained by differences in observable characteristics. The explained part, i.e. the endowments effect, can be either evaluated with the coefficients estimated in specification (1) or (2) of Table 4. The results of the non-linear Blinder-Oaxaca decomposition when the low PE graduate coefficients are used for evaluating the endowments effect are presented in Table 5. A share of $23.5 \%$ of the graduates from low PE families are overqualified, while only $16.1 \%$ of the graduates from high PE families are overqualified. The difference in these percentages, i.e. the total overqualification gap, amounts to 7.4 percentage points. A share of $60.6 \%$ of the overqualification gap can be attributed to the fact that graduates differ in observable characteristics depending on family background. This endowments effect can be interpreted in the following way: If high PE graduates had the same average observable characteristics as low PE graduates, the overqualification gap would be reduced by 4.5 percentage points.

In order to identify through which pathways family background affects the risk of overqualification, I carry out a detailed decomposition of the endowments effect. Social differences in university grades explain a significant share of $6.1 \%$ of the endowments effect. This result is in line with the previous findings that university grades are better among graduates from high PE families and that better grades reduce the risk of overqualification.

The most important contributor to the endowments effect is the choice of university type and subjects. A share of $66.4 \%$ of the endowments effect can be attributed to social differences in these study characteristics. High PE graduates study more often at traditional universities and are more likely to choose subjects with a lower risk of overqualification. If graduates studied the same subjects at the same university type, the social overqualification gap would decrease by 3 percentage points.

Differences in the usage of job search channels significantly account for $8.1 \%$ of the endowments effect. The main cause for this contribution is that low PE graduates more often find their job through a job they had before studying. ${ }^{10}$ The decomposition results do not indicate that graduates from high PE families obtain a lower risk of overqualification because they profit from parental networks in terms of job placement.

A significant part of the endowments effect can be attributed to differences in actions undertaken to improve career prospects. In particular, the higher share of high PE graduates who gained experiences abroad contributes to the endowments effect.

The previous decomposition results are strongly robust against changing the weighting scheme, i.e. using the co-

\footnotetext{
10 The detailed decomposition results presenting each variable separately are not shown in this paper but are available upon request.
} 
Tab. 6 Decomposition of the Overqualification Gap, Weighted by Coefficients of High PE Graduates $\left(\beta_{H}\right)$

\begin{tabular}{llllll}
\hline & Coef. & Std. Err. & $P>|z|$ & $\begin{array}{c}\text { \% of Total } \\
\text { gap }\end{array}$ & $\begin{array}{l}\text { \% of Ex- } \\
\text { plained part }\end{array}$ \\
\hline Low PE & 0.235 & 0.009 & 0.000 & & \\
High PE & 0.161 & 0.009 & 0.000 & & \\
Total overqualification gap & 0.074 & 0.013 & 0.000 & 58.9 & \\
Explained part & 0.044 & 0.011 & 0.000 & 41.1 & \\
Unexplained part & 0.030 & 0.016 & 0.058 & -3.5 \\
Contribution to explained part & & & & 7.2 \\
Vocational education & 0.004 & 0.004 & 0.364 & -0.3 \\
School grade & -0.002 & 0.002 & 0.504 & 53.0 \\
University grade & 0.003 & 0.001 & 0.032 & 12.2 \\
Study duration & 0.000 & 0.000 & 0.621 & 4.6 \\
University types, Subjects & 0.023 & 0.007 & 0.000 & 2.0 \\
How job was found & 0.005 & 0.002 & 0.016 & 8.4 \\
Worked during study & 0.002 & 0.002 & 0.247 & 6.5 \\
Financing of study & 0.001 & 0.007 & 0.902 & -1.0 \\
Dist work, native place & 0.004 & 0.002 & 0.027 & 1.6 \\
Improve career prospects & 0.003 & 0.002 & 0.228 & \\
Future goals & 0.000 & 0.001 & 0.579 & \\
Socio-demographics & 0.001 & 0.003 & 0.813 & \\
\hline Probit & & & \\
\end{tabular}

Probit decomposition computed in Stata employing the procedure by Jann (2008); Explained part evaluated by coefficients of graduates from high PE families. efficients for high PE graduates (Table 6). Social differences in university grades, subject choices, and job search channels remain significant contributors to the endowments effect. The overall contribution of the strategies to improve career prospects becomes insignificant but social differences in gaining experiences abroad remain a significant mediator. Since for high PE graduates the risk of overqualification decreases only if the distance between work and native place exceeds 100 kilometers, the regional mobility significantly contributes to the endowments effect if the high PE coefficients are used as weights. Independently of the weighting scheme, I find no indication that the other proxy variables accounting for financial support and aspiration significantly contribute to the endowments effect. This result might be driven by the lack of precision of the measures for these mediating factors.

Differences in endowments are an important force behind the overqualification gap but a substantial part of approximately $40 \%$ of the gap remains unexplained. ${ }^{11}$ This unexplained part captures how differences in the coefficients of observable characteristics as well as group differences in unobserved characteristics contribute to the overqualification gap. The bulk of the unexplained part can be attributed to the group difference in the constant

\footnotetext{
11 The size of the unexplained part nearly equals the marginal family background effect estimated in the probit regression including all observable mediators.
}

reflecting unobserved heterogeneity. ${ }^{12}$ Unobserved heterogeneity could arise because of missing proxies for relevant characteristics, such as non-cognitive skills, or because of imprecise measurement of mediators included in the analysis.

Discrimination could be a further reason for the significant unexplained part. Employers could value individual characteristics differently for graduates from high PE or low PE families. However, I find no indication that the overqualification gap widens because employers value the graduates' characteristics differently. Differences in the group specific coefficients only play a minor role for the social overqualification gap in my analysis. Individual characteristics, such as university grades, seem to be equally evaluated by the labour market. However, it is possible that employers discriminate applicants on the basis of characteristics that I cannot observe with the data at hand.

\section{Conclusion}

This study finds that family background, as measured by parental education (PE), is a crucial determinant of overqualification at the start of graduates' careers. One year after graduation, the unconditional overqualification gap between graduates from low PE families and high PE

\footnotetext{
12 The detailed decomposition of the unexplained part is available upon request.
} 
families amounts to 7.4 percentage points. The main aim of this study was to uncover which pathways mediate the link between family background and overqualification. In order to account for potential mediators, proxy variables for ability and skills, study characteristics, social capital, financial capital, and aspirations are included in the empirical analysis. Graduates are found to strongly differ in these potential mediators. The effect of family background is reduced but remains highly significant if the potential pathways are accounted for in a probit regression.

Employing a Blinder-Oaxaca approach, I show that roughly $60 \%$ of the overqualification gap can be attributed to the fact that graduates differ in observable characteristics, i.e. the endowments effect. Concerning social differences in ability and skills, I find that differences in university grades significantly contribute to the overqualification gap. In contrast, social differences in school leaving examination grades are found to primarily affect overqualification through the selection into promising subjects. The most important mediator of the family background effect is the social difference in the choice of university type and subjects. This result points to the importance of the horizontal dimension of higher education in the context of parental influences on the risk of overqualification.

A substantial part of approximately $40 \%$ of the overqualification gap remains unexplained by differences in observable mediators. Most of the unexplained part can be attributed to unobserved heterogeneity between graduates from low PE families and graduates from high PE families. An important source for unobserved heterogeneity might be that the proxy variables employed are imprecise measures of mediating factors. Other potentially important factors, such as non-cognitive skills, are not observed. The unexplained family background effect could also arise because of discrimination based on preferences of potential employers. Concerning the individual characteristics included in the present analysis, I find no indication that the overqualification gap widens because employers value characteristics differently. However, it is possible that employers discriminate applicants on the basis of characteristics that are not included in the analysis.

It is difficult to infer policy implications from the findings since it is crucial to disentangle the effect of parental education on overqualification from other potential effects of inherited ability or disposition. However, the result that the incidence of overqualification strongly differs across university types and subjects is striking. In particular, the subjects Medicine \& Law, Teaching, and STEM at traditional universities exhibit considerably low overqualification rates. This finding holds for both types of graduates from low PE and high PE families. Since low PE graduates are significantly less likely to choose these subjects, I find that the social difference in the choice of university type and subject is the most relevant pathway for the social overqualification gap. Therefore, selective measures aiming to inform and motivate students from low PE families to choose promising subjects at traditional universities might reduce their overqualification risk, even though the estimated effects of studying in a particular subject might partly arise due to self-selection.

As this study focuses on graduates observed one year after graduation, no conclusions can be drawn on the correlation between family background and overqualification at later stages of the career cycle. Being overqualified shortly after labour market entry could send negative signals for potential employers in the future and shape long-run career prospects. It is a question for further research whether the persistence of overqualification depends on the social origin of graduates.

Open Access This article is distributed under the terms of the Creative Commons Attribution 4.0 International License (http:// creativecommons.org/licenses/by/4.0/), which permits unrestricted use, distribution, and reproduction in any medium, provided you give appropriate credit to the original author(s) and the source, provide a link to the Creative Commons license, and indicate if changes were made.

\section{References}

Almlund, M., Duckworth, A.L., Heckman, J., Kautz, T.: Personality Psychology and Economics. In: Hanushek, E.A., Machin, S., Wößmann, L. (eds.) Handbook of the Economics of Education, vol. 4, pp. 1-181. Elsevier, Amsterdam (2011)

Anger, S.: The Intergenerational Transmission of Cognitive and NonCognitive Skills During Adolescence and Young Adulthood. SOEPpapers on Multidisciplinary Panel Data Research, No. 4732012. DIW, Berlin (2012)

Anger, S., Heineck, G.: Do Smart Parents Raise Smart Children? The Intergenerational Transmission of Cognitive Abilities. J Popul Econ 23(3), 1105-1132 (2010)

Arcidiacono, P.: Ability Sorting and the Returns to College Major. J Econom 121(1), 343-375 (2004)

Baert, S., Cockx, B., Verhaest, D.: Overeducation at the Start of the Career: Stepping Stone or Trap? Labour Econ 25, 123-140 (2013)

Barone, C., Ortiz, L.: Overeducation among European University Graduates: A Comparative Analysis of its Incidence and the Importance of Higher Education Differentiation. High Educ 61(3), 325-337 (2011)

Bauer, T.: Educational Mismatch and Wages: A Panel Analysis. Econ Educ Rev 21(3), 221-229 (2002)

Becker, R., Haunberger, S., Schubert, F.: Studienfachwahl als Spezialfall der Ausbildungsentscheidung und Berufswahl. J Labour Mark Res 42(4), 292-310 (2010)

Berlingieri, F., Erdsiek, D.: How Relevant is Job Mismatch for German Graduates? ZEW Discussion Paper, No. 12-075. ZEW, Mannheim (2012)

Berlingieri, F., Zierahn, U.: Field of Study, Qualification Mismatch, and Wages: Does Sorting Matter? ZEW Discussion Paper, No. 14-076. ZEW, Mannheim (2014)

Björklund, A., Eriksson, K.H., Jäntti, M.: IQ and Family Background: Are Associations Strong or Weak? Be J Econ Analysis Policy 10(1), 1-14 (2010) 
Black, S.E., Devereux, P.J., Salvanes, K.G.: Like Father, Like Son? A Note on the Intergenerational Transmission of IQ Scores. Econ Lett 105(1), 138-140 (2009)

Blázquez, M., Budría, S.: Overeducation Dynamics and Personality. Educ Econ 20(3), 260-283 (2012)

Blinder, A.S.: Wage Discrimination: Reduced Form and Structural Estimates. J Hum Resour 8(4), 436-455 (1973)

Boll, C., Leppin, J.S.: Unterwertige Beschäftigung von Akademikerinnen und Akademikern: Umfang, Ursachen, Einkommenseffekte und Beitrag zur Geschlechtsspezifischen Lohnlücke. HWWI Policy Paper, No. 75. HWWI, Hamburg (2013)

Bourdieu, P.: Ökonomisches, Kulturelles und Soziales Kapital. In: Kreckel, R. (ed.) Soziale Ungleichheiten, pp. 183-198. Schwartz, Göttingen (1983)

Büchel, F., Mertens, A.: Overeducation, Undereducation, and the Theory of Career Mobility. Appl Econ 36(8), 803-816 (2004)

Büchel, F., Pollmann-Schult, M.: Overeducation and Human Capital Endowments. Int J Manpow 25(2), 150-166 (2004)

Chevalier, A.: Measuring Over-Education. Economica 70(279), 509-531 (2003)

Chevalier, A., Lindley, J.: Overeducation and the Skills of UK Graduates. J Royal Stat Soc Ser A 172(2), 307-337 (2009)

Corak, M., Piraino, P.: The Intergenerational Transmission of Employers. J Labor Econ 29(1), 37-68 (2011)

Daly, M.C., Büchel, F., Duncan, G.J.: Premiums and Penalties for Surplus and Deficit Education: Evidence from the United States and Germany. Econ Educ Rev 19(2), 169-178 (2000)

Diem, A., Wolter, S.C.: Overeducation Among Swiss University Graduates: Determinants and Consequences. J Labour Mark Res 47(4), 313-328 (2014)

Dolton, P., Vignoles, A.: The Incidence and Effects of Overeducation in the UK Graduate Labour Market. Econ Educ Rev 19(2), 179-198 (2000)

Duncan, G., Hoffman, S.: The Incidence and Wage Effects of Overeducation. Econ Educ Rev 1(1), 75-86 (1981)

Erikson, R., Jonsson, J.O.: Social Origin as an Interest-Bearing Asset: Family Background and Labour-Market Rewards among Employees in Sweden. Acta Sociol 41(1), 19-36 (1998)

European Commission: EUROPE 2020: A Strategy for Smart, Sustainable and Inclusive Growth. European Commission, Brussels (2010)

Fairlie, R.W.: An Extension of the Blinder-Oaxaca Decomposition Technique to Logit and Probit Models. J Econ Soc Meas 30, 305-316 (2005)

Fehse, S., Kerst, C.: Arbeiten Unter Wert? Vertikal und Horizontal Inadäquate Beschäftigung von Hochschulabsolventen der Abschlussjahrgänge 1997 und 2001. Beiträge Zur Hochschulforsch 29(1), 72-98 (2007)

Feinstein, L.: Inequality in the Early Cognitive Development of British Children in the 1970 Cohort. Economica 70(277), 73-97 (2003)

Gautier, P.A., Teulings, C.N.: Sorting and the Output Loss due to Search Frictions. J Eur Econ Assoc 13(6), 1136-1166 (2015)

Green, F., McIntosh, S.: Is There a Genuine Under-Utilization of Skills Amongst the Over-Qualified? Appl Econ 39(4), 427-439 (2007)

Green, F., McIntosh, S., Vignoles, A.: Overeducation and Skills - Clarifying the Concepts. CEP Discussion Paper, No. 435. CEP, London (1999)

Grönqvist, E., Vlachos, J., Öckert, B.: The Intergenerational Transmission of Cognitive and Non-Cognitive Abilities. IFN Working Paper, No. 884. IFN, Stockholm (2011)

Hartog, J.: Over-Education and Earnings: Where are We, Where Should We Go? Econ Educ Rev 19(2), 131-147 (2000)

Heckman, J.J., Stixrud, J., Urzua, S.: The Effects of Cognitive and Noncognitive Abilities on Labor Market Outcomes and Social Behavior. J Labor Econ 24(3), 411-482 (2006)
Hersch, J.: Education Match and Job Match. Rev Econ Stat 73(1), 140-144 (1991)

Jacob, M., Klein, M.: Der Einfluss der Bildungsherkunft auf den Berufseinstieg und die Ersten Erwerbsjahre von Universitätsabsolventen. Beiträge Zur Hochschulforsch 1, 8-37 (2013)

Jann, B.: The Blinder-Oaxaca Decomposition for Linear Regression Models. Stata J 8(4), 453-479 (2008)

Jonsson, J.O., Grusky, D.B., Di Carlo, M., Pollak, R., Brinton, M.C.: Microclass Mobility: Social Reproduction in Four Countries. Am J Sociol 114(4), 977 (2009)

Kleibrink, J.: Inept or Badly Matched? - Effects of Educational Mismatch in the Labor Market. Labour 30(1), 88-108 (2015)

Klein, M.: Higher Education and Non-Pecuniary Returns in Germany: Tracing the Mechanisms Behind Field of Study Effects at the Start of the Career. Ir Educ Stud 30(2), 253-270 (2011)

Korpi, T., Tåhlin, M.: Educational Mismatch, Wages, and Wage Growth: Overeducation in Sweden, 1974-2000. Labour Econ 16(2), 183-193 (2009)

Lörz, M.: Mechanismen Sozialer Ungleichheit beim Übergang ins Studium: Prozesse der Status- und Kulturreproduktion. In: Becker, R., Solga, H. (eds.) Soziologische Bildungsforschung, pp. 302-324. Springer, Köln (2012)

Lucas, S.R.: Effectively Maintained Inequality: Education Transitions, Track Mobility, and Social Background Effects. Am J Sociol 106(6), 1642-1690 (2001)

McCormick, B.: A Theory of Signalling During Job Search, Employment Efficiency, and "Stigmatised" Jobs. Rev Econ Stud 57(2), 299-313 (1990)

McGowan, M.A., Andrews, D.: Labour Market Mismatch and Labour Productivity: Evidence from PIAAC Data. OECD Economics Department Working Papers, No. 1209. OECD, Paris (2015)

McGuinness, S.: University Quality and Labour Market Outcomes. Appl Econ 35(18), 1943-1955 (2003)

Neumark, D.: Employers' Discriminatory Behavior and the Estimation of Wage Discrimination. J Hum Resour 23(3), 279-295 (1988)

Oaxaca, R.: Male-Female Wage Differentials in Urban Labor Markets. Int Econ Rev (Philadelphia) 14(3), 693-709 (1973)

OECD: Economic Policy Reforms 2010: Going for Growth. OECD Publishing, Paris (2010)

Poropat, A.E.: A Meta-Analysis of the Five-Factor Model of Personality and Academic Performance. Psychol Bull 135(2), 322 (2009)

Quintini, G.: Right for the Job: Over-Qualified or Under-Skilled? OECD Social, Employment and Migration Working Papers, No. 120. OECD, Paris (2011)

Reimer, D., Pollak, R.: Educational Expansion and its Consequences for Vertical and Horizontal Inequalities in Access to Higher Education in West Germany. Eur Sociol Rev 26(4), 415-430 (2009)

Robst, J.: College Quality and Overeducation. Econ Educ Rev 14(3), 221-228 (1995)

Sattinger, M.: Assignment Models of the Distribution of Earnings. J Econ Lit 31(2), 831-880 (1993)

Sohn, K.: The Role of Cognitive and Noncognitive Skills in Overeducation. J Labor Res 31(2), 124-145 (2010)

Tsai, Y.: Returns to Overeducation: A Longitudinal Analysis of the US Labor Market. Econ Educ Rev 29(4), 606-617 (2010)

Van de Werfhorst, H.G., Luijkx, R.: Educational Field of Study and Social Mobility: Disaggregating Social Origin and Education. Sociology 44(4), 695-715 (2010)

Weiss, F., Klein, M.: Soziale Netzwerke und Jobfindung von Hochschulabsolventen - Die Bedeutung des Netzwerktyps für Monetäre Arbeitsmarkterträge und Ausbildungsadäquatheit. Z Soziol 40(3), 228-245 (2011)

Yun, M.-S.: Decomposing Differences in the First Moment. Econ Lett 82(2), 275-280 (2004) 